\title{
METHOD OF OPERATIONAL LIFE'S INCREASING OF TRANSPORT'S PARTS DUE TO USAGE OF COATINGS BASED ON EPOXY MATRIX MODIFIED BY MALEINIC ANHYDRIDE WITH IMPROVED THERMAL PHYSICAL PROPERTIES
}

\author{
Danyl Zhytnyk
}

\author{
Kherson state maritime academy, Kherson, Ukraine
}

\begin{abstract}
Summary. The use of a new method of operational life increase of the transport means parts due to the introduction of polymer-based modified materials has been substantiated in the paper under discussion. It is shown that the use of matrices based on epoxy diane oligomers is quite promising direction in protective coatings formation. Some active additives have been applied to improve the properties of epoxy matrices on preliminary stage of their formation. The use of maleinic anhydride modifier containing active to the interphase interaction functional groups is promising as well.

Epoxy diane oligomer has been used as the main component for the matrix in the composite formation. The hardener polyethelenepolyamine has been used to link the epoxy compositions enabling to harden the materials at room temperature. The choice of maleinic anhydride as a modifier to improve thermal-physical properties of the developed materials has been substantiated.

It has been found that to form a composite material or a protective coating with improved thermalphysical properties it is necessary to apply maleinic anhydride as a modifier in epoxy matrix in the following ratio: $q=0,5$ pts.wt. per $q=100$ pts.wt. of epoxy oligomer ED-20. In this case the material has been formed where, comparing with nonmodified matrix, the indices of glass transition temperature are being increased from $T_{c}=327 \mathrm{~K}$ to $T_{c}=335 \mathrm{~K}$, heat resistance (by Martenson) from $T=341 \mathrm{~K}$ to $\mathrm{T}=362 \mathrm{~K}$, and thermal coefficient of linear expansion in the range of temperatures $\Delta T=303 \ldots 423 \mathrm{~K}$ is being decreased from $\alpha=9,9 \times 10^{-5} K^{-1}$ to $\alpha=4,4 \times 10^{-5} \mathrm{~K}^{-1}$.

It has been proved that the maleinic anhydride content in the matrix with its small fraction $(q=0,5$ pts.wt.) has activated the processes of interphase interaction in epoxy CM structure formation, resulted in the increase of number of both physical and chemical bonds per polymer volume unit. This process will involve the increase of gel fraction degree in $C M$, and, correspondingly, both the cohesion and thermal-physical properties of modified CM have been improved. The developed material under discussion could be efficiently used as a matrix in formation of protective coatings which are to be operated under high temperatures conditions and dynamic or static loadings.
\end{abstract}

Key words: epoxy composite, heat resistance, thermal coefficient of linear expansion, glass transition temperature.

Problem statement. It is well known [1-4], that some parts of modern means of transport, including river and maritime ones, have always been affected by static and dynamic loads as well as by sign-alternating temperature. This is the main reason of the operational life reduction due to the early ageing of the materials. Taking into account the abovementioned facts, one of the most urgent problems nowadays has been the development of new technologies aimed at increase of reliability of the equipment due to the use of new materials meeting the latest requirements.

We must admit that one of the methods to increase the operational life of transport vehicles parts is the use of modified protective coatings for the means of transport. In this case such coatings must have not only improved physical-mechanical properties, but thermalphysical ones as well. One of the directions to implement the above-mentioned method is the 
use of modified polymer materials where active to physical-chemical interphase interaction additives will allow to obtain synergistical effect to improve properties, including thermalphysical ones, polymer composites and protective coatings on their basis.

Analysis of the latest studies and publications. The authors [5-8] have shown that one of the directions to use the widely spread method of operational life increase of the transport means parts is the introduction of modified protective coatings on modern vessels. In this case it is necessary to apply only active additives which interact with polymeric matrix. Here the use of maleinic anhydride as an initiator of such interaction is quite promising. It is characterized by its active carbonyl and carboxyl groups which will allow to improve cohesion and, hence, thermal-physical properties of protective coatings functional use due to the interaction with the functional groups of the main polymer.

Paper purpose - study the influence of the content of maleinic anhydride modifier on the thermal-physical properties of epoxy composites to increase the operational life of transport means parts.

Materials and technique of the research. Epoxy diane oligomer ED-20 (GOST 10587-84) has been used as a base in polymeric matrix formation. The hardener of cold hardening polyethelenepolyamine PEPA (TU 6-05-241-202-78) has been used in polymerization of the developed materials based on epoxy resin.

Maleinic anhydride (MA) has been used as a modifier to improve the properties of epoxy composite materials (CM). The modifier was applied to the matrix with content from 0,10 to 2,00 pts.wt. per 100 pts.wt. of epoxy oligomer ED-20. The molecular formula of the modifier: $\mathrm{C}_{4} \mathrm{H}_{2} \mathrm{O}_{3}$. The mole weight of $\mathrm{MA}-98,057 \mathrm{~g} / \mathrm{mole}$. It looks like a white substance. Density $-\rho=1,314 \mathrm{~g} / \mathrm{cm}^{3}$

Epoxy composites have been formed by the following technology [5, 6]: the epoxide was heated to the temperature $T=353 \pm 2 \mathrm{~K}$ and the exposure at the given temperature within the time interval $\tau=20 \pm 0,1 \mathrm{~min}$; hydrodynamic shift of oligomer and the fractures of filling within the time interval $\tau=10 \pm 0,1 \mathrm{~min}$; ultrasound treatment of the composition within the time interval $\tau=1,5 \pm 0,1 \mathrm{~min}$; the composition cooling till the room temperature within the time interval $\tau=60 \pm 5 \mathrm{~min}$; the hardener applying and the composition mixing within the time interval $\tau=5 \pm 0,1 \mathrm{~min}$. The CM was hardened by the mode: test pieces formations and their exposure within the time interval $\tau=12,0 \pm 0,1$ hour at temperature $T=293 \pm 2 \mathrm{~K}$, heating at speed $v=3 \mathrm{~K} / \mathrm{min}$ to the temperature $T=393 \pm 2 \mathrm{~K}$, exposure within the time interval $\tau=2,0 \pm 0,05$ hour, slow cooling up to the temperature $T=293 \pm 2 \mathrm{~K}$. To stabilize the structural processes in the composite the test pieces have been exposed during $\tau=24$ hour in the open air at temperature $T=293 \pm 2 \mathrm{~K}$ with the further experimental tests conducting.

Thermal coefficient of linear expansion (TCLE) and heat resistance (HR) of CM have been studied in the article under discussion. Heat resistance (by Martenson) of CM has been found according to GOST 21341-75. Thermal coefficient of linear expansion (TCLE) of the materials has been calculated by the relative deformation-temperature influence curve. The relative deformation has been determined by the change of the specimen length at the temperature increase (GOST 15173-70).

Results of the study and their discussion. It is well known that one of the most important properties of epoxy composite materials (CM) being operated under heat field impact conditions is the glass transition temperature. The latter characterizes the heat processes taking place in the structure of materials under transition from visco-elastic to glasslike state conditions. We must admit, that the glass transition temperature has been determined on the basis of dilatometric curves analysis under heating and cooling of the developed materials conditions. 
The conducted experiments have proved that (fig. 1) the glass transition temperature of epoxy matrix is equal to $T_{c}=327 \mathrm{~K}$. The application of maleinic anhydride modifier (MA) in the epoxy matrix has caused the increase $T_{c}$ of modified matrix. In particular, it is shown (fig. 1), that the presence of additive equal to $q=0,25$ pts.wt. in the heterogeneous system per 100 pts.wt. of epoxy oligomer ED-20 has provided the formation of the composite whose glass transition temperature is equal to $T_{c}=332 \mathrm{~K}$. The best indices of this characteristics of the whole range of the materials under study the CM has been differentiated, filled with MA of the content $q=0,50$ pts.wt. per 100 pts.wt. of epoxy oligomer ED-20. Such composite has been characterized by the glass transition temperature $-T_{c}=335 \mathrm{~K}$, which is $\Delta T_{c}=8 \mathrm{~K}$ higher than the same indices of the nonmodified epoxy matrix. The further increase of the modifier content could not result in the matrix glass transition temperature increase. On the contrary, the properties are getting worse under the additive content conditions $q=2,00$ pts.wt. when the glass transition temperature of $\mathrm{CM}$ is $T_{c}=325 \mathrm{~K}$, which is lower than $T_{c}$ of the parent matrix.

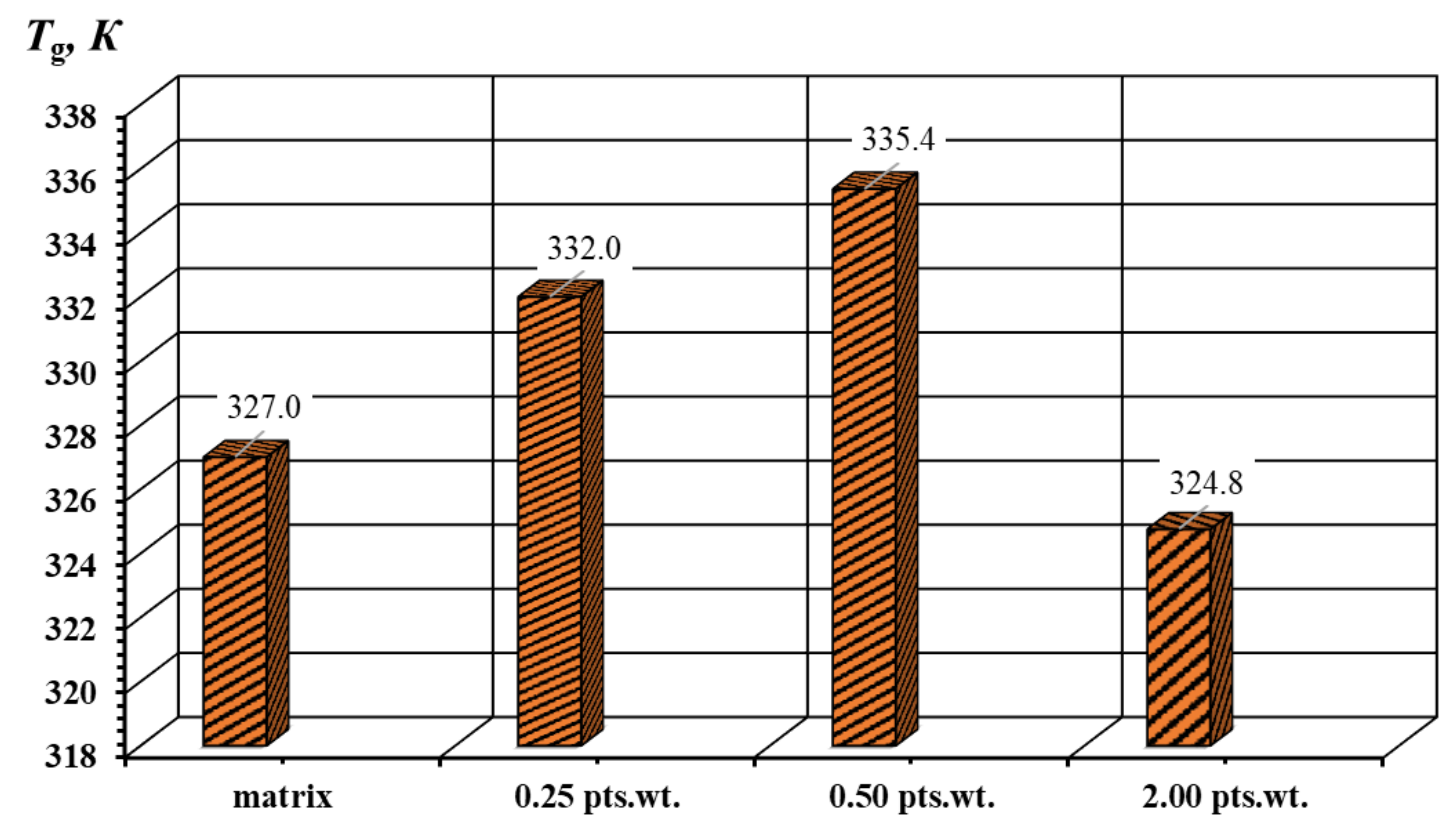

Figure 1. Dependence of the CM glass transition temperature on the maleinic anhydride modifier content: parent matrix (control specimen); $q=0,25$ pts.wt.; $q=0,50$ pts.wt.; $q=2,00$ pts.wt

To prove the above-mentioned results of the tests heat resistance (by Martenson) of the parent matrix and modified materials has been studied additionally. The conducted experiments have proved that (fig. 2) the heat resistance of the parent nonmodified epoxy matrix equals to $T=341 \mathrm{~K}$. The application of a modifier irrespective of its concentration in the epoxy matrix has contributed to the monotonous increase of the indices of heat resistance that was clearly enough shown on the histogram (fig. 2). We can state that the maleinic anhydride content in the matrix at some small amount ( $q=0,25$ pts.wt.) has activated the processes of interphase interaction in epoxy $\mathrm{CM}$ structure formation resulted in the number of both physical and chemical bonds per unit of the polymer volume has increased. It has involved the increase of gel fraction degree in the CM and, 
correspondingly, both the cohesion and thermal-physical properties of the modified CM have been improved as well.

Furthermore, the higher content of the additive up to $0,50 \ldots 2,00$ pts.wt. in the epoxy oligomer has facilitated the increase of the heat resistance indices (by Martenson) from $T=341 \mathrm{~K}$ (for epoxy matrix) to $T=362 \ldots 367 \mathrm{~K}$. Due to the method of IR-spectroscopy it has been proved that it was caused by the interaction in the process of carbonyl and carboxyl groups polymerization of the modifier with epoxy and hydroxyl groups of epoxy oligomer. Therefore, it has been resulted in the increase of density of the polymer three-dimensional network due to which the heat resistance of the developed CM has increased.

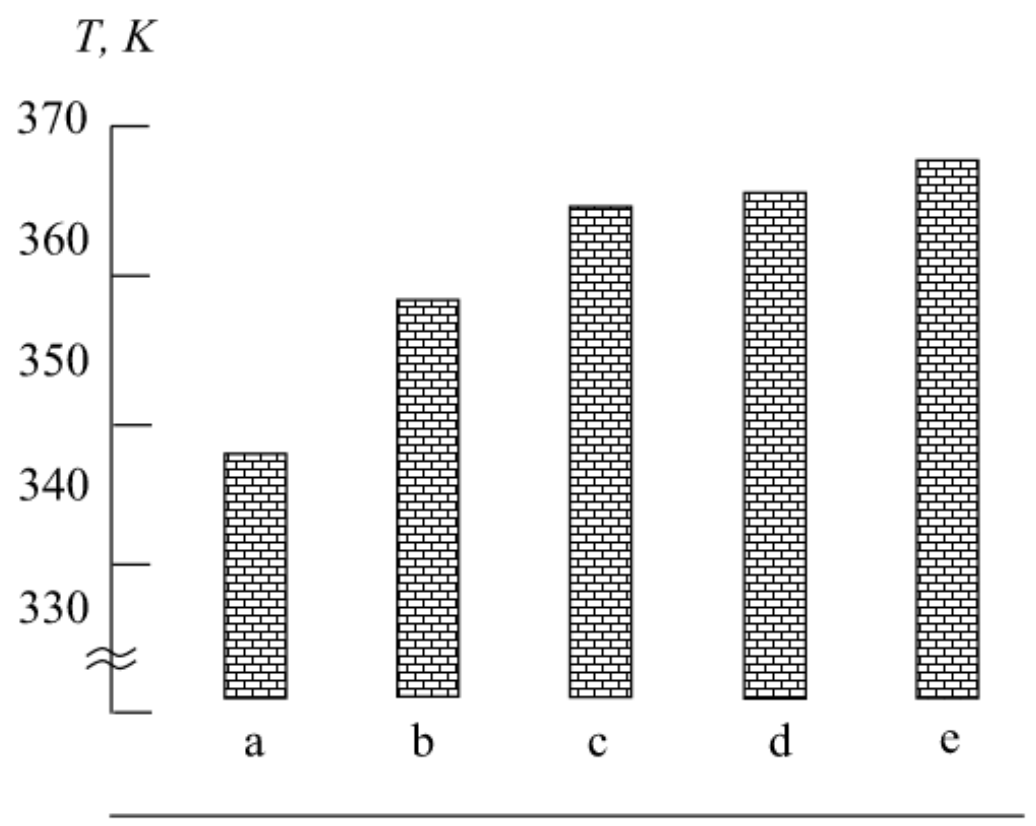

Figure 2. Dependence of the CM heat resistance (by Martenson) on the maleinic anhydride modifier content: a) parent matrix (control specimen); b) $q=0,25$ pts.wt.; c) $q=0,50$ pts.wt.; d) $q=1,00$ pts.wt.; e) $q=2,00$ pts.wt

The thermal coefficient of linear expansion (TCLE) of epoxy composites in different temperature ranges of the tests has been studied in the paper under discussion. Taking into account the operating conditions of the developed materials, the following temperature intervals of the tests have been chosen $\Delta T, \mathrm{~K}: 303 \ldots 323,303 \ldots 373,303 \ldots 423,303 \ldots 473$. We must admit, that thermal coefficient of linear expansion (TCLE) of the developed CM have been calculated while analyzing the dilatometric curves shown on fig. 3 .

The analysis of the obtained results has allowed to claim that in the first chosen by us ranges of tests $(\Delta T=303 \ldots 323 \mathrm{~K}$ та $\Delta T=303 \ldots 373 \mathrm{~K})$ the introduction of a modifier has provided the $\mathrm{CM}$ formation having 2,2..2,5 times smaller thermal coefficient of linear expansion (TCLE) comparing with the matrix without regard to the additive content (table. 1). As it was mentioned above, this can be explained by active interaction of the modifier micro molecules with active side hydroxyl and epoxy groups of an epoxy oligomer resulted in the increase of gel formation degree of the modifies matrix. 


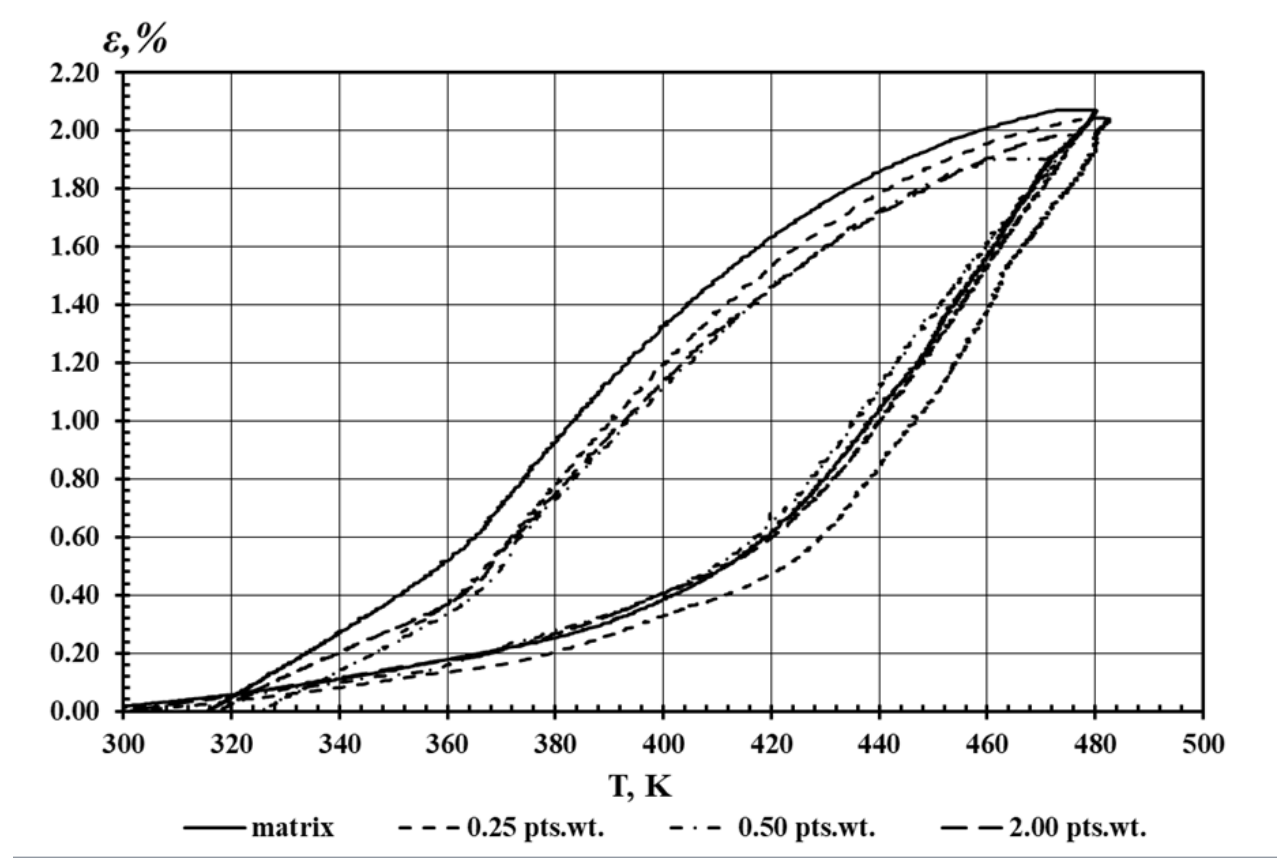

Figure 3. Dilatometric curves of CM with different content of maleinic anhydride modifier

Table 1

Thermal coefficient of linear expansion (TCLE) of CM at different range of temperatures

\begin{tabular}{|c|c|c|c|c|c|}
\hline \multirow{2}{*}{ № } & \multirow{2}{*}{$\begin{array}{c}\text { Additive ratio, } \\
q \text {, pts.wt. }\end{array}$} & \multicolumn{4}{|c|}{ Thermal coefficient of linear expansion (TCLE), $\alpha \times 10^{-5}, \mathrm{~K}^{-1}$} \\
\cline { 3 - 6 } & & \multicolumn{4}{|c|}{ Temperatures ranges of the test, $\Delta T, \mathrm{~K}$} \\
\hline 1 & Matrix & $6, \ldots 323$ & $303 \ldots 373$ & $303 \ldots 423$ & $303 \ldots 473$ \\
\hline 2 & 0,25 & 2,5 & 6,8 & 9,9 & 10,9 \\
\hline 3 & 0,50 & 2,7 & 3,5 & 4,1 & 10,4 \\
\hline 4 & 2,00 & 2,9 & 3,1 & 4,4 & 9,8 \\
\hline
\end{tabular}

The results of the thermal coefficient of linear expansion (TCLE) study in the areas of increased temperatures have been quite interesting from both the scientific and practical point of view as well. It was found (table 3.1), that in the area of glass transition temperature $(\Delta T=303 \ldots 423 \mathrm{~K})$ thermal coefficient of linear expansion (TCLE) of the parent epoxy matrix was equal to $\alpha=9,9 \times 10^{-5} \mathrm{~K}^{-1}$. The use of additive of the content $q=0,25 \ldots 2,00 \mathrm{pts}$. wt. has facilitated the formation of CM whose thermal coefficient of linear expansion (TCLE) has been $1,8 \ldots 2,4$ times lower.

In the areas of increased temperatures $(\Delta T=303 \ldots 473 \mathrm{~K})$ the following results have been observed. Thermal coefficient of linear expansion (TCLE) of the epoxy matrix is $\alpha=10,9 \times 10^{-5} \mathrm{~K}^{-1}$, but in the developed composites this coefficient is getting lower up to $\alpha=(9,8 \ldots 10,7) \times 10^{-5} \mathrm{~K}^{-1}$. Moreover, we should admit, that the material containing the modifier of the content $q=0,50$ pts.wt. has been characterized by the minimal values of the thermal coefficient of linear expansion (TCLE) $\left(\alpha=9,8 \times 10^{-5} \mathrm{~K}^{-1}\right)$ for the given area of tests.

Due to the results of the conducted study dealing with the thermal-physical properties of the composites as a complex, we can say that a modifier has made a great impact on the 
structure and characteristics of the materials. Moreover, we can assume that the most efficient has proved to be the maleinic anhydride content $q=0,5$ pts.wt. as an additive in the polymer matrix per 100 pts.wt. of epoxy oligomer ED-20.

Conclusions. On the basis of the study results dealing with the thermal-physical properties of composites related to the maleinic anhydride modifier content we can state the following. To form a composite material or a protective coating with improved thermalphysical properties it is worth to apply a maleinic anhydride modifier of amount $q=0,5$ pts.wt. per $q=100$ pts.wt. of epoxy oligomer ED-20 in the epoxy matrix. In this case the material has been formed where, comparing with the nonmodified matrix, the indices of the glass transition temperature are getting higher from $T_{c}=327 \mathrm{~K}$ to $T_{c}=335 \mathrm{~K}$, heat resistance (by Martenson) from $T=341 \mathrm{~K}$ to $T=362 \mathrm{~K}$, but the thermal coefficient of linear expansion (TCLE) within the range of temperatures $\Delta T=303 \ldots 423 \mathrm{~K}$ is getting lower from $\alpha=9,9 \times 10^{-5} \mathrm{~K}^{-1}$ to $\alpha=4,4 \times 10^{-5} \mathrm{~K}^{-1}$.

We can state that the maleinic anhydride content in the matrix at its some small amount ( $q=0,25$ pts.wt.) has activated the processes of interphase interaction in epoxy CM structure formation resulted in the number of both physical and chemical bonds per unit of the polymer volume has increased. It has involved the increase of gel fraction degree in the CM and, correspondingly, both the cohesion and thermal-physical properties of the modified CM have been improved as well. The developed material can be successfully applied as a matrix in protective coatings formation which are to be used under increased temperatures impact and static or dynamic loadings conditions.

\section{References}

1. Taher A. A. Fyzyko-khymyya polymerov. M.: Nauchnuy myr, 2007. 573 p.

2. Vilens'kyy V. O., Demchenko V. L., Kercha Yu. Yu., Shut M. I. Doslidzhennya termomekhanichnykh ta teplofizychnykh vlastyvostey nanokompozytiv na osnovi poliepoksydu ta dyspersnykh napovnyuvachiv riznoyi pryrody. Fizyka kondensovanykh vysokomolekulyarnykh system. 2009. Vol. 13. P. 18-23.

3. Kocherhyn Yu. S., Kulyk T. A., Hryhorenko T. Y. Kleevye kompozytsyy na osnove modyfytsyrovannykh эpoksydnykh smol. Plastycheskye massy. 2005. No. 10. P. 9-16.

4. Voronkov A. H., Yartsev V. P. Epoksydnye polymerrastvory dlya remonta y zashchyty stroytel'nykh yzdelyy y konstruktsyy: uchebnoe posobye. Tambov: Yzd-vo Tamb. hos. tekhn. un-ta, 2006. 92 p.

5. Buketov A. V., Nehrutsa R. Yu., Yatsyuk V. M. Vplyv modyfikatora 2,4-dyaminoazobenzol-4'karbonovoyi kysloty na adheziyni vlastyvosti ta zalyshkovi napruzhennya zakhysnykh polimernykh pokryttiv. Naukovi notatky. Luts'k: LNTU. Vol. 65. 2019. P. 30-38.

6. Buketov A. V., Sharko A., Cherniavska T., Ivchenko T., Yatsyuk V., Okipnyi I. Study of heat resistance of epoxy matrix modified by phthalimide for protection of vehicles. Scientific Journal of TNTU. 2020. Vol. 99. No. 3. P. 93-101. DOI: https://doi.org/10.33108/visnyk_tntu2020.03.093

7. Buketov A., Sharko A., Cherniavska T., Ivchenko T., Yatsyuk V., Okipnyi I. Study of heat resistance of epoxy matrix modified by phthalimide for protection of vehicles. Visnyk TNTU. 2020. No. 3. P. 93-101. DOI: : https://doi.org/10.33108/visnyk_tntu2020.03.093

8. Buketov A. V., Sizonenko O. M., Kruglyj D. G., Cherniavska T. V., Appazov E. S., Klevtsov K. M., Lypian Ye. V. Influence of synthesized iron-carbides mixture on properties of epoxy coatings for transport. Journal of Engineering and Applied Science. 2020. Vol. 67. Issue 7. P. 1633-1648. URL: https://www. jeasonline.org/paper/1157/preview.

\section{Список використаної літератури}

1. Тагер А. А. Физико-химия полимеров. М.: Научный мир, 2007. 573 с.

2. Віленський В. О., Демченко В. Л., Керча Ю. Ю., Шут М. І. Дослідження термомеханічних та теплофізичних властивостей нанокомпозитів на основі поліепоксиду та дисперсних наповнювачів різної природи. Фізика конденсованих високомолекулярних систем. 2009. Вип. 13. С. 18-23.

3. Кочергин Ю. С., Кулик Т. А., Григоренко Т. И. Клеевые композиции на основе модифицированных эпоксидных смол. Пластические массы. 2005. № 10. С. 9-16.

4. Воронков А. Г., Ярцев В. П. Эпоксидные полимеррастворы для ремонта и защиты строительных изделий и конструкций: учебное пособие. Тамбов: Изд-во Тамб. гос. техн. ун-та, 2006. 92 с. 
Method of operational life's increasing of transport's parts due to usage of coatings based on epoxy matrix modified by maleinic anhydride with improved thermal physical properties

5. Букетов А. В., Негруца Р. Ю., Яцюк В. М. Вплив модифікатора 2,4-диаміноазобензол-4'- карбонової кислоти на адгезійні властивості та залишкові напруження захисних полімерних покриттів. Наукові нотатки. Вип. 65. 2019. С. 30-38.

6. Buketov A. V., Sharko A., Cherniavska T., Ivchenko T., Yatsyuk V., Okipnyi I. Study of heat resistance of epoxy matrix modified by phthalimide for protection of vehicles. Scientific Journal of TNTU. 2020. Vol. 99. No. 3. P. 93-101. DOI: https://doi.org/10.33108/visnyk_tntu2020.03.093

7. Buketov A., Sharko A., Cherniavska T., Ivchenko T., Yatsyuk V., Okipnyi I. Study of heat resistance of epoxy matrix modified by phthalimide for protection of vehicles. Visnyk TNTU. 2020. No. 3. P. 93-101. DOI: https://doi.org/10.33108/visnyk_tntu2020.03.093

8. Buketov A. V., Sizonenko O. M., Kruglyj D. G., Cherniavska T. V., Appazov E. S., Klevtsov K. M., Lypian Ye. V. Influence of synthesized iron-carbides mixture on properties of epoxy coatings for transport. Journal of Engineering and Applied Science. 2020. Vol. 67. Issue 7. P. 1633-1648. URL: https://www.jeasonline.org/paper/1157/preview.

\title{
УДК 667.64:678.026
}

\section{МЕТОД ЗБІЛЬШЕННЯ РЕСУРСУ ДЕТАЛЕЙ ТРАНСПОРТНИХ ЗАСОБІВ ЗА РАХУНОК ВИКОРИСТАННЯ ПОКРИТТІВ НА ОСНОВІ МОДИФІКОВАНОЇ МАЛЕЇНОВИМ АНГІДРИДОМ ЕПОКСИДНОЇ МАТРИЦІ 3 ПОЛІПШЕНИМИ ТЕПЛОФІЗИЧНИМИ ВЛАСТИВОСТЯМИ}

\author{
Данил Житник \\ Херсонська державна морська академія, Херсон, Україна
}

\begin{abstract}
Резюме. Обгрунтовано використання нового методу збільшення ресурсу роботи деталей засобів транспорту за рахунок упровадження модифікованих матеріалів на полімерній основі. Показано, щя перспективним при формуванні захисних покриттів є використання зв'язувачів на основі епоксидних діанових олігомерів. Для покращення властивостей епоксидних матрищь на попередній стадії їх формування вводять активні добавки. Перспективним є застосування модифікатора малейнового ангідриду, який містить активні до міжфазової взаємодї функиіональні групи.

Як основний компонент для зв'язувача при формуванні композитів вибрано епоксидний діановий олігомер. Для зиивання епоксидних композицій використано твердник поліетиленполіамін, щуо дозволяє затверджувати матеріали при кімнатних температурах. Обтрунтовано вибір у вигляді модифікатора малеїнового ангідриду для поліпшення теплофізичних властивостей розроблених матеріалів.

Встановлено, щзо для формування композитного матеріалу чи захисного покриття з поліпшеними теплофізичними властивостями у епоксидний зв'язувач доцільно вводити модифікатор малеїновий ангідрид у кількості $q=0,5$ мас.ч. на $q=100$ мас.ч. епоксидного олігомера ЕД-20. У такому випадку формується матеріал, у якому, порівняно з немодифікованою матрицею, показники температури склування збільшуються від $T_{c}=327 \mathrm{~K}$ до $T_{c}=335 \mathrm{~K}$, теплостійкості (за Мартенсом) від $T=341 \mathrm{~K}$ до $T=362 \mathrm{~K}$, а термічний коефічієнт лінійного розширення у області температур $\Delta T=303 \ldots 423 \mathrm{~K}$ змениується від $\alpha=9,9 \times 10^{-5} \mathrm{~K}^{-1}$ до $\alpha=4,4 \times 10^{-5} \mathrm{~K}^{-1}$.

Доведено, щзо вміст у зв'язувачі малеїнового ангідриду за незначного вмісту ( $q=0,5$ мас.ч.) активує прочеси міжфазової взаємодї при структуроутворенні епоксидних КМ, у результаті чого збільшується кількість як фізичних, так і хімічних зв'язків на одиницю об'єму полімера. Це передбачає збільшення ступеня гель-фракиї у КМ, $i$, відповідно, поліпшуються як когезійні, так $i$ теплофізичні властивості модифікованих КМ. Розроблений матеріал доиільно використовувати у вигляді матриці при формуванні захисних покриттів, які заплановано експлуатувати в умовах впливу підвищених температур і динамічних чи статичних навантажень.
\end{abstract}

Ключові слова: епоксидний композит, теплостійкість, термічний коефіцієнт лінійного розширення, температура склування.

https://doi.org/10.33108/visnyk_tntu2021.02.140

Отримано 19.03.2021 